\title{
PEMBAYARAN REKENING LISTRIK PASCABAYAR DI PT. PLN PERSERO BATUSANGKAR MENURUT UNDANG-UNDANG NOMOR 08 TAHUN 1999 TENTANG PERLINDUNGAN KONSUMEN DAN HUKUM EKONOMI SYARIAH
}

\author{
Gusti Marlina \\ Jorong Nan IX, Nag. Salimpaung, Kec. Salimpaung, Kab. Tanah Datar \\ gustimarlina19@yahoo.com
}

\begin{abstract}
The main problem in this research is Payment of Postpaid Electricity Account at PT. PLN Persero Batusangkar According to law Number 08 of 1999 on consumer Protection and Sharia Economic Law. This study aims to determine whether the system of electricity bill payment at PT. PLN Persero Batusangkar has been in line with the existing laws in Indonesia and the view of Islamic Law. Type of research is field research. Data collection techniques used are observation, interviews, and documentation. Data analysis tecnique is done by data reduction, data presentation, and conclusion. From the research that has been done in the field can be concluded in the Aplication of Law Number 08 Year 1999 About Legal Protection Against Consumers in payment of electricity bill postpaind not in line with Law Number 08 of 1999 on the protection of consumer law contained in article 4 letter $c$ stated that the right to information is correct, clear and honest about the condition and guarantee of goods and/or services. And Payment of Postpaid Electricity Account According to Sharia Economic Law is Gharar because Ujrah paid to PT. PLN Persero Batusangkar is not known value by one of the parties and this is not in line with the terms of Ujrah in Ijarah agreement and not fulfillment of one of the pillars in Ijarah agreement, thus the contract is not valid.
\end{abstract}

Keyword: Pembayaran, Rekening Listrik Pascabayar

\section{PENDAHULUAN}

Dalam kehidupan saat ini, listrik menjadi hal penting dan keberadaannya menjadi pendukung untuk mewujudkan suatu pembangunan. Peningkatan kemakmuran masyarakat serta upaya mendorong peningkatan taraf hidup, tidak terlepas dari penyediaan tenaga listrik. Pentingnya energi listrik bagi masyarakat dapat ditunjukkan dengan besarnya penggunaan listrik oleh masyarakat baik untuk konsumsi rumah tangga maupun industri dan perdagangan dalam skala lokal maupun nasional.

Begitu sangat pentingnya listrik dalam kehidupan di dalam masyarakat, maka penyediaan tenaga listrik dikuasai oleh 
negara yang pelaksanaanya dilakukan oleh PT. PLN atau Perusahaan Listrik Negara selaku Badan Usaha Milik Negara. Pelaksanaan usaha penyediaan tenaga listrik dibentuk berdasarkan peraturan perundang-undangan yang berlaku sebagai pemegang kuasa usaha ketenagalistrikan di Indonesia. Model pengelolaan tenaga listrik semacam ini didasarkan harapan pemerintah agar industri ketenagalistrikan transparan, efisien, dan ramah lingkungan dapat tercipta untuk mendukung pertumbuhan ekonomi nasional dan juga meningkatkan kesejahteraan rakyat. Sebagai Badan Usaha Milik Negara, pengelolaan listrik seharusnya semaksimal mungkin, sehingga pemanfaatan dan penyediaan listrik dapat dijalankan secara merata dan bermutu.

Dalam rangka pemberian perlindungan terhadap konsumen, pemerintah telah mengeluarkan sebuah peraturan perundang-undangan mengenai perlindungan konsumen dalam bentuk Undang-Undang Nomor 08 Tahun 1999 tentang Perlindungan Konsumen, yang untuk selanjutnya disingkat dengan UUPK. Pelaku usaha sebagaimana yang dinyatakan dalam Pasal 7 UUPK juga harus bertangggung jawab dalam menjalankan kegiatan usaha dan atas barang dan/atau jasa yang dihasilkannya.
Dalam hal ini bentuk barang atau jasa yang dihasilkan oleh PLN adalah menyediakan tenaga listrik bagi kepentingan umum dan menyediakan tenaga listrik dalam jumlah dan mutu yang memadai. Namun tentunya pada praktek kehidupan sehari-hari di dalam masyarakat, tidak bisa dihindari adanya beberapa permasalahan yang berkaitan dengan jual beli listrik, dalam konteks ini ada beberapa permasalahan yang terjadi diantaranya mulai dari ketidakjelasan perhitungan biaya tagihan listrik pascabayar yang selalu berubah-ubah pada setiap perhitungan pemakaian energi listrik, atau yang biasa disebut KWH (Kilowatt Hour) meter yang sama. Pencatatan pemakaian KWH meter yang dilakukan oleh petugas ke rumahrumah yang kedatangannya tidak menentu yang mengakibatkan ketidakjelasan biaya perhitungan yang ditetapkan oleh pihak PLN Persero Batusangkar, dan penetapan biaya pemakaian yang di perkiraperkirakan dari pemakaian sebelumnya oleh pihak PLN Persero Batusangkar.

Berdasarkan data yang penulis peroleh dari beberapa konsumen pemakai listrik pascabayar di PT. PLN Persero Batusangkar yang terdapat pada struk pembayaran tagihan listrik pascabayar di PT. PLN Persero Batusangkar. Seperti yang terdapat pada struk pembayaran rekening 
listrik pascabayar atas nama Lina (nama samaran), nomor pelanggan 132.200.136. XXX, daya 16.500 untuk pembayaran bulan April 2015 dengan pemakaian KWH 1.600 dengan biaya tagihan Rp. 2.637.485,-. Kemudian untuk pemakaian yang sama atas nama Lina pembayaran bulan Mei 2015 dengan pemakaian KWH 1.600 dengan biaya tagihan Rp. 1.776.366,-

Selanjutnya, pada struk pembayaran rekening listrik pascabayar atas nama Bainar (nama samaran), nomor pelanggan 132.200.136.XXX, daya 16.500 untuk pembayaran bulan Maret 2015 dengan pemakaian KWH 2.200 dengan tagihan Rp. 3.496.952,-. Untuk pembayaran bulan April 2015 dengan pemakaian KWH 2.200 dengan biaya tagihan Rp. 6.809.954,-Kemudian untuk pemakaian atas nama Bainar, untuk pembayaran bulan Mei 2015 dengan pemakaian KWH 4.138 dengan biaya tagihan Rp. 1.764.130,- .

Dalam beberapa struk pembayaran di atas, terlihat permasalahan tentang ketidakjelasan perhitungan biaya tagihan rekening listrik pascabayar yang selalu berubah-ubah pada setiap perhitungan pemakaian energi listrik yang sama, dan juga pemakaian KWH yang lebih besar tetapi pembayaranya kecil bahkan sebaliknya, pemakaian KWH yang lebih sedikit tetapi pembayarannya lebih besar.
Berdasarkan realita yang telah dipaparkan di atas maka penulis mengkaji lebih dalam tentang bagaimanakah Pembayaran Rekening Listrik Pascabayar di PT. PLN Persero Batusangkar Menurut Undang-Undang Nomor 08 tahun 1999 Tentang Perlindungan Konsumen dan Hukum Ekonomi Syariah.

\section{KAJIAN PUSTAKA}

\section{Pengertian Perlindungan Konsumen}

Pengertian perlindungan konsumen terdapat dalam Pasal 1 angka 1 UndangUndang Nomor 8 Tahun 1999 tentang Perlindungan Konsumen (selanjutnya disebut Undang-Undang Perlindungan Konsumen/UUPK), yaitu segala upaya yang menjamin adanya kepastian hukum untuk memberi perlindungan kepada konsumen. Rumusan pengertian perlindungan konsumen yang terdapat dalam Pasal 1 angka 1 Undang-Undang Perlindungan Konsumen tersebut cukup memadai. Kalimat yang menyatakan "segala upaya yang menjamin adanya kepastian hukum untuk memberi perlindungan kepada konsumen", diharapkan sebagai benteng untuk meniadakan tindakan sewenangwenang yang merugikan konsumen. (Miru, 2010: 1)

Pembayaran Rekening Listrik Pascabayar di PT. PLN Persero Batusangkar... 


\section{Gharar dalam Hukum Ekonomi Islam}

\section{a. Pengertian Gharar}

Al-Gharar ( الغرر ) secara lughawi berarti al-khatr (resiko, berbahaya), dan al-taghrir adalah melibatkan diri dalam sesuatu yang gharar. Lafadz Gharar (dari segi tata bahasa) adalah merupakan isim (kata benda). (Syahatah, dkk, 2005: 146). Al-Gharar (الغرر ) artinya keraguan, tipuan atau tindakan yang bertujuan untuk merugikan pihak lain. Suatu akad mengandung unsur penipuan, karena tidak ada kepastian, baik mengenai ada atau tidak ada obyek akad, besar kecil jumlah maupun menyerahkan obyek akad tersebut.

\section{b. Kategori-Kategori Gharar}

Kategori gharar yang diharamkan, gharar dihukumi haram bilamana terdapat salah satu kriteria berikut: ( Al Subaily: 25)

1) Jumlahnya besar. Jika gharar yang sedikit tidak mempengaruhi keabsahan akad, seperti: pembeli mobil yang tidak mengetahui bagian dalam mesin atau pembeli saham yang tidak mengetahui rincian aset perusahaan. Ibnu Qayyim berkata," gharar dalam jumlah sedikit atau tidak mungkin dihindari niscaya tidak mempengaruhi keabsahan akad, berbeda dengan gharar besar atau gharar yang mungkin dihindari". (zaadul maad jilid.V hal. 820).
Al Qarafi berkata," gharar dalam bai'ada 3 macam:

a) Gharar besar membatalkan akad, seperti menjual burung di angkasa.

b) Ghararyang sedikittidakmembatalkan akad dan hukumnya mubah, seperti ketidakjelasan pondasi rumah atau ketidakjelasan jenis benang qamis yang dibeli.

c) Gharar sedang, hukumnya diperselisihkan oleh para ulama. Apakah boleh atau tidak." ( furuuq jilid.III hal. 265). Al Baji berkata," gharar besar yaitu rasionya dalam akad terlalu besar sehingga orang mengatakan bai' ini gharar". Muntaqa jilid. 5 hal. 41).

2) Keberadaannya dalam akad mendasar. Jika gharar dalam akad hanya sebagai pengikut tidak merusak keabsahan akad. Dengan demikian menjual binatang ternak yang bunting, menjual binatang ternak yang menyusui dan menjual sebagian buah yang belum matang dalam satu pohon dibolehkan. Walaupun janin, susu dan sebagian buah tersebut tidakjelas, karena keberadaanya hanya sebagai pengikut.

3) Akad yang mengandung gharar bukan termasuk akad yang dibutuhkan orang banyak. Jika suatu akad mengandung 
gharar dan akad tersebut dibutuhkan oleh orang banyak hukumnya sah dan dibolehkan. Ibnu Taimiyah berkata," mudharat gharar di bawah riba, oleh karena itu diberi rukhsah (keringanan) jika dibutuhkan oleh orang banyak, karena jika diharamkan mudharatnya lebih besar daripada dibolehkan". (Qawaid nuraniyah hal.140).

\section{Hukum Akad ljarah}

\section{a. Pengertian Ijarah}

Menurut terminologi/istilah Ijarah adalah akad sewa menyewa dengan mengambil manfaat sesuatu dari orang lain dengan membayar sesuatu dengan perjanjian yang telah ditentukan dengan syarat-syarat. (Zaidun, dkk, 1997 :183).

Ijarah secara etimologi berarti sewa menyewa atau upah mengupah, sedangkan imbalan ijarah atau upah (ujrah) adalah "balasan dari suatu kerja". Secara istilah berarti "menjadikan suatu manfa`ah (jasa) sebagai milik, baik manfaat itu berasal dari barang ('ain) atau pekerjaan ('amal) manusia tertentu dengan imbalan (ujrah) ditentukan pula, baik imbalan tersebut berupa harta ‘ain (barang), dayin (hutang), atau manfa'ah (jasa). Demikian pula artinya menurut terminologi syara'. Pada dasarnya, ijarah didefinisikan sebagai hak untuk memanfaatkan barang jasa dengan membayar imbalan tertentu, menurut Fatwa Dewan Syariah Nasional No. 09 / DSN-MUI/IV/2000, ijarah adalah akad pemindahan hak guna (manfaat) atas suatu barang atau jasa dalam waktu tertentu melalui pembayaran sewa/upah, tanpa diikuti dengan pemindahan kepemilikan barang itu sendiri. Dengan demikian, dalam akad ijarah tidak ada perubahan kepemilikan, tetapi hanya perpindahan hak guna saja dari yang menyewakan kepada penyewa. (Muhammad, tth : 147)

\section{b. Dasar Hukum Ijarah}

Dasar-dasar hukum ijarah adalah AlQur'an, As-Sunnah, dan Al-Ijma' serta landasan hukum operasional lainnya.

1) Dasar hukum ijarah dalam Al-Qur'an adalah :

a) Surat at-Thalaq ayat 6:

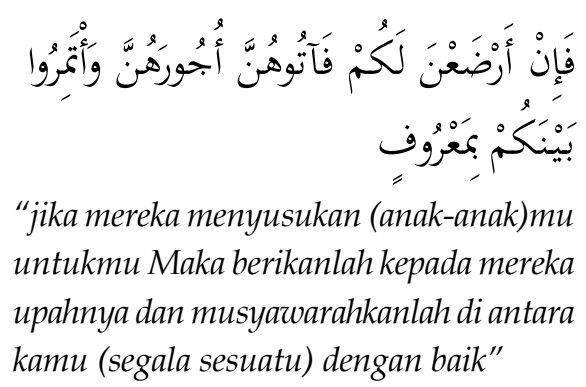

2) Adapun dasar hukum dari hadits Nabi diantaranya adalah:

a) Al Bukhari meriwayatkan dari Ibnu Abbas bahwa Nabi SAW, artinya:

"Telah menceritakan kepada kami Musa bin Isma'il telah menceritakan kepada kami 
Wuhaib telah menceritakan kepada kami Ibnu Thowus dari bapaknya dari Ibnu 'Abbas radliallahu 'anhuma berkata; Nabi shallallahu 'alaihi wasallam berbekam dan memberi upah tukang bekamnya"

\section{c. Rukun dan Syarat-Syarat Ijarah}

1) Rukun Ijarah

Rukun dari ijarah sebagai suatu transaksi adalah akad atau perjanjian kedua belah pihak, yang menunjukkan bahwa transaksi itu telah berjalan secara suka sama suka. (Syarifuddin: 217)

Adapun unsur yang terlibat dalam transaksi ijarah itu adalah:

a) Orang yang menggunakan jasa (mūjir)

b) Orang yang memberikan jasa (musta'jir)

c) Objek transaksi yaitu jasa (ma'jur)

d) Imbalan atau jasa yang diberikan disebut upah atau sewa (ujrah)

2) Syarat ijarah

Syarat-syarat tersebut meliputi:

a) 'Aqid yaitu berakal dan dapat membedakan (baik dan buruk)

b) Sigat akad antara $m u^{\prime} j i r$ dan musta'jir (Asy-Syifa', 1994: 174)

c) Ujrah (upah)

Upah (ujrah) dapat digolongkan menjadi 2, yaitu:
(1) Upah yang telah disebutkan (ajr almusamma)

(2) Upah yang sepadan (ajr al-mițli) (Huda, 2008: 230)

Dengan demikian, persyaratan penetapan upah atas objek ijarah yang terdapat dalam pasal 6 Peraturan Ketua Badan Pengawas Pasar Modal dan Lembaga Keuangan Nomor: PER-04/BL/2007 tentang akad-akad yang digunakan dalam kegiatan perusahaan pembiayaan berdasarkan prinsip syariah, wajib memenuhi ketentuanketentuan sebagai berikut:

(1) Besarnya harga ujrah atas objek ijarah dan cara pembayaran ditetapkan menurut kesepakatan yang dibuat dalam akad secara tertulis.

(2) Alat pembayaran ujrah atas objek ijarah adalah berupa uang atau bentuk lain yang memiliki nilai yang sama yang tidak bertentangan dengan prinsip syariah. (Anshori, 2010:82)

Dari uraian-uraian yang dikemukakan diatas, dapat diambil kesimpulan bahwa penentuan upah belum dijelaskan secara rinci dalam al-Qur'an maupun hadis tetapi secara umum harus sesuai dengan perjanjian kedua belah pihak. 


\section{METODE PENELITIAN}

Pendekatan penelitian yang digunakan dalam penelitian jurnal ini adalah penelitian hukum normatif atau sering disebut dengan penelitian doctrinal, karena objek kajiannya adalah dokumen peraturan perundangundangan, hukum ekonomi syariah dan bahan pustaka. Untuk menguatkan bahan hukum primer yang berupa peraturan perundang-undangan, turut dimasukkan pula wawancara dengan pihak PT. PLN Persero Batusangkar dan beberapa konsumen listrik pascabayar sebagai data sekunder. Penelitian ini merupakan penelitian lapangan (Field research) yaitu penelitian dengan mengumpulkan sumber data dari objek penelitian (masyarakat atau komunitas sosial) secara langsung di daerah penelitian (Sopyan, 2002: 32). Kemudian data yang di dapat dari lapangan tersebut diolah dan dianalisa dengan menggunakan jenis penelitian kepustakaan (Library research) yang dilakukan dengan cara diolah dan dianalisa dengan menggunakan Undangundang perlindungan konsumen dan hukum ekonomi syariah, yang dilakukan dengan cara membaca, dan meneliti teoriteori yang berhubungan dengan masalah yang berkaitan dengan masalah pokok untuk dilakukan klasifikasi dan interpretasi data.

\section{TEMUAN PENELITIAN DAN PEMBAHASAN}

\section{Pelaksanaan Pembayaran Rekening Listrik Pascabayar di PT. PLN Persero Batusangkar}

PT. PLN. (Persero) Rayon Batusangkar sekarang memiliki 5 Kantor Pelayanan di seluruh wilayahnya guna memudahkan dalam memberikan pelayanan yang handal diantaranya adalah Kantor Pelayanan Ramabatan, Salimpaung, Sungayang, Sungai Tarab dan Simabur. Temuan penelitian tentang ketidakjelasan perhitungan biaya tagihan listrik pascabayar di PT. PLN Persero Batusangkar yang perhitungan tersebut selalu berubahubah pada setiap perhitungan pemakaian energi listrik, atau yang biasa disebut KWH (Kilowatt Hour) meter yang sama.

Pada kondisi lain pencatatan pemakaian KWH meter yang dilakukan oleh petugas PLN ke rumah-rumah yang kedatangannya tidak menentu mengakibatkan ketidakjelasan biaya perhitungan yang ditetapkan oleh pihak PLN Persero Batusangkar. Disebabkan kondisi yang demikian, pada saat terjadi komplen oleh konsumen karena pembengkakkan tagihan akibat perhitungan yang tidak jelas tersebut, penetapan biaya pemakaian diperkirakirakan dari pemakaian sebelumnya oleh pihak PLN Persero Batusangkar. 
Beberapa permasalahan yang penulis gambarkan di atas dapat diperhatikan/ dianalisa berdasarkan data yang telah penulis kumpulkan berikut. Berdasarkan data yang penulis peroleh dari beberapa konsumen pemakai listrik pascabayar di PT. PLN Persero Batusangkar yang terdapat pada struk pembayaran tagihan listrik pascabayar di PT. PLN Persero Batusangkar, dapat dicermati hal-hal sebagai berikut:

a. Rekening listrik pascabayar atas nama Lina (nama samara), nomor pelanggan 132.200.136.XXX, daya 16.500 Volt Ampere (VA) untuk pembayaran bulan April 2015 dengan pemakaian KWH 1.600 dengan biaya tagihan Rp. 2.637.485,-. Kemudian untuk pemakaian yang sama atas nama Lina (nama samara) pembayaran bulan Mei 2015 dengan pemakaian KWH 1.600 dengan biaya tagihan Rp. 1.776.366.-

Berdasarkan data di atas dapat dicermati bahwa pelanggan dengan No. 132.200.136.XXX menggunakan listrik dengan Daya/Tegangan 16.500 Volt Ampere (VA). Pada bulan April 2015 pelanggan mengunakan energi listrik sebanyak 1.600 KiloWatt Hertz (KWH), sehinggan harus membayar tagihan listrik sebanyak Rp. 2.637.485, Kemudian pada bulan Mei 2015 pelanggan tercatat menggunakan energi listrik sebanyak 1.600 KiloWatt Hertz (KWH), dan membayar tagihan untuk pemakaian bulan tersebut sebanyak Rp. 1.776.366.-. dapat dicermati bahwa dengan jumlah pemakaian energi listrik yang sama pada bulan April dan Mei, yaitu sebanyak 1.600 KWH terdapat perbedaan jumlah tagihan yang berbeda. Pelanggan yang pada bulan April membayar tagihan sebanyak Rp. 2.637.485,-, pada bulan Mei hanya membayar tagihan sebanyak Rp. 1.776.366.-. sehingga terdapat penurunan jumlah tagihan.

b. Rekening listrik pascabayar atas nama Bainar (nama samara), nomor pelanggan 132.200.136.XXX, daya 16.500 Volt Ampere (VA) untuk pembayaran bulan Maret 2015 dengan pemakaian KWH 2.200 dengan jumlah tagihan Rp. 3.496.952,-. Untuk pembayaran bulan April 2015 dengan pemakaian KWH 2.200 dengan biaya tagihan Rp. 6.809.954,-. Kemudian untuk pemakaian atas nama Bainar, untuk pembayaran bulan Mei 2015 dengan pemakaian KWH 4.138 dengan biaya tagihan sejumlah Rp. 1.764.130,- .

Berdasarkan data di atas dapat dicermati bahwa pelanggan dengan No. 132.200.136.XXX menggunakan 
listrik dengan Daya/Tegangan 16.500 Volt Ampere (VA). Pada bulan Maret 2015 pelanggan mengunakan energi listrik sebanyak 2.200 KiloWatt Hertz (KWH), sehinggan harus membayar tagihan listrik sebanyak Rp. 3.496.952,. Kemudian pada bulan April 2015 pelanggan tercatat menggunakan energi listrik sebanyak 2.200 KiloWatt Hertz (KWH), dan membayar tagihan untuk pemakaian bulan tersebut sebanyak Rp. 6.809.954,-. dapat dicermati bahwa dengan jumlah pemakaian energi listrik yang sama pada bulan Maret dan April, yaitu sebanyak 2.200 KWH terdapat perbedaan jumlah tagihan yang berbeda. Pelanggan yang pada bulan Maret membayar tagihan sebanyak Rp. 3.496.952,-, pada bulan April membayar tagihan sebanyak Rp. 6.809.954,-. sehingga terdapat lonjakan jumlah tagihan hampir 100 $\%$. Sementara pada bulan Mei jumlah pemakaian energi listrik pelanggan mengalami peningkatan hampir 100 $\%$, yaitu sebangak $4.138 \mathrm{KWH}$, hanya saja pelanggan mengalami penurunan jumlah tagihan yang sangat signifikan, yaitu sebesar Rp. 1.764.130,-.

Berdasarkan data yang diperoleh dari struk pembayaran tagihan di atas, terlihat permasalahan tentang ketidakjelasan perhitungan biaya tagihan rekening listrik pascabayar yang berubah-ubah pada setiap perhitungan pemakaian energi listrik yang sama.

Ketidaksesuaian Rekening Pemakaian Tenaga Listrik K-1. Kategori I (K-I) yaitu apabila terjadi ketidaksesuaian parameter yang menyebabkan kelebihan maupun kekurangan tagih pada Pelanggan diakibatkan oleh antara lain :

1. Faktor perkalian meter Alat Pengukur setempat tidak sama dengan faktor kali yang tertulis pada rekening.

2. Pemakaian tenaga listrik pada Pelanggan yang peruntukannya tidak sesuai dengan daya dan/atau golongan tarif pada alas hak yang sah / surat perjanjian jual beli tenaga listrik.

3. Faktor koreksi pada rekening yang ditagihkan tidak sesuai dengan sistem sambungan pengukuran yang terpasang pada pelanggan setempat.

4. Faktor pemakaian trafo pada data induk pelanggan tidak sesuai dengan setempat.

5. Pembacaan angka register Alat Pengukur KWH dan kVArh setempat tidak sesuai dengan angka meter pada rekening. 
6. Kegagalan mutasi yang menyebabkan tagihan rekening tidak sesuai dengan ketentuan yang berlaku.

7. Time switch tidak berfungsi sebagaimana mestinya.

\section{Penerapan Undang-Undang Nomor 08 Tahun 1999 Tentang Perlindungan Hukum terhadap Konsumen dalam Pembayaran Rekening Listrik Pascabayar.}

Pengaturan tentang hak konsumen dijumpai dalam Pasal 4 Undang-Undang Perlindungan Konsumen diatur mengenai hak konsumen. Hak konsumen diatur dalam Pasal 4. Pelaksanaan jual beli listrik pascabayar, pada pertengahan pelaksanaan ada ketidakjelasan dalam hal pembayaran listrik dapat merugikan pelanggan. Pada Pasal 4 huruf c dinyatakan bahwa hak atas informasi yang benar, jelas dan jujur mengenai kondisi dan jaminan barang dan/atau jasa. Pembayaran listrik yang kadang merugikan banyak pelanggan tentang ketidakjelasan perhitungan biaya tagihan rekening listrik pascabayar yang selalu berubah-ubah pada setiap perhitungan pemakaian energi listrik yang sama dan juga pemakaian KWH yang lebih besar tetapi pembayaranya kecil bahkan sebaliknya, pemakaian KWH yang lebih sedikit tetapi pembayarannya lebih besar. Jelas kondisi tersebut pelanggan tidak mendapatkan informasi yang benar, jelas, dan jujur mengenai biaya pembayaran.
Kelemahan yang mendasar atas peristiwa pembayaran rekening listrik adalah kurangnya advokasi konsumen dalam proses penyelesaian sengketa seperti yang dicantumkan dalam Pasal 4 huruf e Undang-Undang Perlindungan Konsumen. Pada awal pemasangan PT. PLN Persero tidak pernah menjelaskan bila dikemudian hari timbul permasalahan, langkah-langkah yang dapat dilakukan atau diambil oleh pelanggan untuk mendapatkan penyelesaian permasalahan. Pelanggan biasanya disarankan untuk membuat pengaduan ke bagian keluhan pelanggan. Pasal 4 huruf g Undang-Undang Perlindungan Konsumen menyatakan konsumen berhak untuk diperlakukan atau dilayani secara benar dan jujur serta tidak diskriminatif.

Pasal 4 huruf h Undang-Undang Perlindungan Konsumen menyatakan konsumen berhak untuk mendapatkan kompensasi, ganti rugi dan/atau penggantian, apabila barang dan/atau jasa yang diterima tidak sesuai dengan perjanjian atau tidak sebagaimana mestinya. Kemudian dalam Pasal 7 huruf g Undang-Undang Perlindungan Konsumen diatur bahwa pelaku usaha memiliki kewajiban memberi kompensasi, ganti rugi dan/atau penggantian apabila barang dan/atau jasa baran dan/atau jasa 
yang diterima atau dimanfaatkan tidak sesuai dengan perjanjian. Pada prakteknya sistem kompensasi ini telah ada, bahwa konsumen berhak menerima kompensasi bila standar minimum pelayanan atau yang biasa disebut dengan TMP terlanggar. Berkait dengan Kesalahan pembacaan kWh meter; dan/atau Waktu koreksi kesalahan rekening angka standar adalah 10\% dari biaya tertanggung yang melewati nilai TMP. Penggantian ini dapat diajukan kepada PLN dan akan dievaluasi oleh teknisi PLN sebelum memberikan ganti rugi. Mengenai sanksi berupa pengurangan pembayaran listrik, hanya diberlakukan pada tiga poin diatas, yakni: lama gangguan, jumlah gangguan dan/atau kesalahan baca meter. Menurut ketentuan yang berlaku, tindakan yang merugikan konsumen berdasar SK Dirjen Listrik dan Pemanfaatan Energi Nomor 114 Tahun 2002, konsumen berhak untuk mendapatkan kompensasi (gantirugi).

Sebagian besar pelanggan masih tidak tahu apa saja yang menjadi hak-haknya dan mereka juga tidak tahu kemana harus melaporkan apabila haknya terlanggar. Ada kecendrungan PT. PLN Persero tertutup atas kebijakannya, menyampaikan informasi bila ditanya oleh pelanggan. Hal tersebut melanggar Pasal 4 huruf $b$ Undang-Undang Perlindungan Konsumen, pelaku usaha wajib memberikan informasi yang benar, jelas dan jujur mengenai kondisi dan jaminan barang dan/atau jasa.

\section{Perlindungan Hukum Terhadap Konsumen Dalam Pembayaran Rekening Listrik Pascabayar Menurut Hukum Ekonomi Syariah.}

Di dalam surat Perjanjian Jual Beli Tenaga Listrik (SPJBTL) terlihat di dalamnya tidak memenuhi salah satu syarat sahnya ijarah. Terdapat ketidakjelasan pembayaran ujrah yang harus dibayarkan, karena di dalam surat perjanjian hanya dibunyikan "harga jual tenaga listrik pascabayar sesuai Tarif Tenaga Listrik yang berlaku. Apabila terjadi perubahan ketentuan/ peraturan, maka para pihak sepakat akan menyesuaikan harga jual dimaksud dengan ketentuan/peraturan yang baru. Sebagaimana yang telah ditentukan di dalam hukum Islam. Rukun perjanjian tersebut sebagai berikut: a) Para pihak yang membuat akad. b) Penyertaan kehendak para pihak. c) Objek akad. d) Tujuan akad.

Kebijakan ujrah yang diterapkan oleh pihak PT. PLN Persero harus sesuai dengan persetujuan pemerintah atau pemerintah daerah atas harga jual tenaga listrik dan sewa jaringan tenaga listrik dengan persetujuan Dewan Perwakilan Rakyat Republik Indonesia. Ujrah yang dibayarkan kepada PT. PLN Persero tidak diketahui 
nilainya oleh salah satu pihak dan ini belum sejalan dengan syarat dari ujrah dalam akad ijarah. Dalam ekonomi Islam Ijarah adalah akad/kontrak pengambilan manfaat dari barang atau jasa orang lain yang diketahui dengan upah dan waktunya yang diganti dengan suatu penggantian yang sesuai dengan kesepakatan. (Hasan: 236)

Ketidakjelasan ujrah terhadap manfaat yang harus dibayarkan atau diserahkan kepada pihak PT. PLN Persero adalah gharar. Dalam hukum ekonomi pengertian gharar adalah keraguan, tipuan atau tindakan yang bertujuan untuk merugikan pihak lain. Suatu akad mengandung unsur penipuan, karena tidak ada kepastian, baik mengenai ada atau tidak ada obyek akad, besar kecil jumlah maupun menyerahkan obyek akad tersebut. Gharar semacam ini haram karena terdapat salah satu kriteria, yaitu jumlah ketidakjelasannya yang besar. Gharar yang jumlah ketidakjelasannya besar dan dengannya dapat membatalkan akad. Gharar ini timbul karena sebab jasa yang diserahkan tetapi tidak sama spesifikasinya ujrah seperti yang dijanjikan.

\section{PENUTUP}

Penerapan Undang-Undang No. 08 Tahun 1999 Tentang Perlindungan Hukum Terhadap Konsumen dalam pembayaran rekening listrik pascabayar belum sejalan dengan Undang-Undang No. 08 tahun 1999 tentang perlindungan hukum terhadap konsumen yang terdapat pada Pasal 4 huruf c dinyatakan bahwa hak atas informasi yang benar, jelas dan jujur mengenai kondisi dan jaminan barang dan/atau jasa. Serta Pembayaran Rekening Listrik Pascabayar Menurut Hukum Ekonomi Syariah adalah gharar karena Ujrah yang dibayarkan kepada PT. PLN Persero tidak diketahui nilainya oleh salah satu pihak dan ini belum sejalan dengan syarat dari ujrah dalam akad ijarah dan tidak terpenuhinya salah satu rukun dalam akad ijarah, dengan demikian akad tersebut tidak sah. Karena tujuan akad salah satu prinsip dasar dari suatu transaksi dimana suatu transaksi haruslah dilakukan secara benar dan tidak saling merugikan orang lain, karena bertransaksi secara benar mempunyai tujuan agar hakikat dari harta yang dimiliki oleh manusia tersebut tetap terjaga dengan baik.

\section{Saran}

Dari penelitian ini, untuk menjadi bahan pertimbangan bagi PT. PLN Persero Batusangkar perlu adanya perhitungan yang jelas dan akurat dalam perhitungan biaya pemakaian konsumen dalam pencatatan KWH yang dilakukan kerumah-rumah oleh petugas pencatatan. Serta adanya 
sikap terbuka dari PT.. PLN Persero selaku pemegang kuasa Usaha Ketenagalistrikan di Indonesia. Terbuka terhadap masukan, kritikan dan pengaduan, khusunya dari pelanggan. Konsumen/Pelanggan listrik adalah subyek yang mempunyai keinginan dan harapan akan adanya perbaikan kualitas pelayanan dari PT. PLN Persero. Hal ini hanya bisa dipahami jika ada jalinan komunikasi yang baik kepada PT. PLN Persero.

\section{DAFTAR PUSTAKA}

Anshori Abdul Ghofur, 2010. Hukum Perjanjian Islam Di Indonesia (Konsep, Regulasi, Dan Implementasi), Yogyakarta: Gadjah Mada University Press.

Miru Ahmadi dan Sutarman Yodo, 2010. Hukum Perlindungan Konsumen, Jakarta, Rajawali Pers.

Al-Husni Al-Imam Taqiyuddin Abu Bakar, Kifayatul Akhyar Fii Alli Ghayatil Ikhtishaar, 1997. (terj) oleh Ahmad Zaidun dan A. Ma'ruf Asrori, Surabaya : PT. Bina Ilmu, cet. Ke-1.

Arsip PT. PLN Persero Batusangkar.

Kristiyanti Celina Tri, 2009. Hukum Perlindungan Konsumen, Jakarta: Sinar Grafika.

Djuwaini Dimyauddin, 2010. Pengantar Fiqih Muamalah, Yogyakarta: Pustaka Pelajar.
Nasional Fatwa Dewan Syariah No. 09/ DSN-MUI/IV/2000, Tentang Pembiayaan Ijarah, ed. 1, 2001, DSNMUI, BI, www.mps.fai-umj.ac.id

Syahatah Husain, dkk, 2005. Transaksi dan Etika Bisnis Islam, Jakarta: Visi Insani Publishing, cet. ke- 1 .

Rusyd Ibnu, Bidayatul Al-Mujtahid wa Nihayah Al-Muqtashid, juz 11, h. 218, sebagaimana dikutip dalam Rahmat Syafi'I, 2004. Fiqih Muamalah, Bandung : Pustaka Setia, cet Ke-11.

Muhammad, t.th. Manajemen Pembiayaan Bank Syariah, Yogyakarta: UPP AMPYKPN.

Huda Nurul, 2008, Ekonomi Makro Islam: Pendekatan Teoritis, Jakarta: Kencana Prenada Media Group.

Undang-Undang No 30 Tahun 2009 Tentang Tarif Tenaga Listrik.

prabayar Standart prosedur pelayanan, 2010. Prosedur Pelayanan Listrik Prabayar. Jakarta: PT.PLN persero.

Syamsuddin Abu al-Faraj 'Abdurrahman ibn Abu 'Umar Muhammad ibn Ahmad ibn Qudamah al-Maqdisiy (w.682H), al-Syarh al-Kabir 'ala Matan al-Muqni, (Beirut: Dâr al-Kitâb al'Arabiy, tp.th.), jil. 6. 
Undang-undang No. 8 tahun 1999 Tentang Subaily Yusuf Al, t.th. Fiqh Perbankan Perlindungan Konsumen, www. Syariah: Pengantar figh muamalat dan djlpe.esdm.go.id aplikasinya dalam ekonomi modern,

Sopyan Yayan, 2002. Pengantar Metode terjemahan Erwandi Tarmizi.

Penelitian, Ciputat, UIN Syarif Hidayatullah Jakarta. 